\title{
Biofilm Production by Multi Drug Resistant Bacterial Pathogens Isolated From Patients in Intensive Care Units in Egyptian Hospitals
}

\section{Elhabibi $\mathrm{T}^{1 *}$ and Ramzy $\mathbf{S}^{2}$}

${ }^{1}$ Department of Microbiology and Immunology, Egyptian Russian University, Egypt

${ }^{2}$ Department of Microbiology and Immunology, Al-Azhar University, Egypt

\begin{abstract}
Antibiotic resistance among Multi drug resistant (MDR) Gram negative bacteria causing hospital acquired infections poses a great threat in ICU patients. The treatment of such infections has become increasingly problematic, due to their intrinsic and/or acquired resistance to variable classes of antibiotics. Moreover, the demonstrated ability of these bacteria to grow as biofilm is believed to have a major role in their ability to resist various antibiotics.

The aim of this study is to evaluate the role of the selected genes in biofilm formation in 3 significant MDR bacterial isolates (Acinetobacter baumannii and Pseudomonas aeruginosa and Stenotrophomonas maltophilia). In this study a total of 625 non replicated Gram negative non-fermenter bacterial isolates were isolated from different clinical specimens from intensive care units from hospitals in Egypt. These bacterial isolates were identified biochemically, API20E and genetically.

The antibiogram of all isolates was determined and revealed that all isolates were MDR and colistin was the most potent antibiotic against all $A$. baumannii and $P$. aeruginosa isolates. While trimethoprim/sulfamethoxazole combination was the most potent against all S. maltophilia isolates. Detection of biofilm formation of isolates was done by Tube method. While, Quantification of biofilm formation was done by the microtiter plate method using crystal violet (CV) assay. Screening for some selected genes responsible for biofilm formation was done by PCR as bap gene which is responsible for biofilm formation in A. baumannii, rhll gene in $P$. aeruginosa strains and $r m / A$, spgM, rpfF genes in S. maltophilia. The results revealed the presence of these genes in both strong and weak biofilm producer isolates. These final results showed the significance of these genes in biofilm formation.
\end{abstract}

Keywords: Multi drug resistant; Bacterial pathogens; Intensive care

\section{Introduction}

Biofilm is considered as an accumulation of bacteria and their extracellular products forming a structured community on a surface [1]. Biofilms are complex bioactive structures composed of one or more bacterial species protected by a matrix of extracellular polysaccharides. Biofilm formation is initiated by the initial attachment of bacteria to a solid surface. The adherent cells form micro colony and accumulation of clusters of cells within bacterial polysaccharides and other types of matrices [2]. By time, the biofilm becomes thicker, denser and, when disrupted, leads to the dissemination of microbial cells [3]. Bacteria in biofilms become more resistant to antibiotics [4]. In the medical setting, biofilm-associated infections cause a significant problem that arises from the surface of different indwelling devices such as intravenous catheters, alloplastic materials, hydrocephalus shunts and others [2].

Multi drug resistant A. baumannii, P. aeruginosa and S. maltophilia species are nowadays widely spread. By nature, these microorganisms are more resistant than other Gram negative bacteria due to many reasons; the most significant reason is their outer membrane that is less permeable and their ability to form biofilm [5]. The ability of bacteria to form biofilms represents a prominent factor associated with A. baumannii, $P$. aeruginosa and $S$. maltophilia virulence. Strains of $A$. baumannii form biofilms in-vitro, and some of the molecular mechanisms associated with this phenotype have been extensively studied; the main gene associated with biofilm formation is bap (encoding the biofilm-associated protein [Bap]) [6].

One of the most common biofilm forming bacteria is $P$ a aeruginosa [7]. P. aeruginosa has been extensively studied for genetic determinants that contribute to form biofilm. Recently, it was discovered that $P$. aeruginosa quorum-sensing (QS) signal molecules termed auto- inducers (AI) play a major role in the differentiation process. Also, $P$. aeruginosa has two hierarchical QS systems known as las and rhl $[8,9]$. It has been frequently reported that one rhl-controlled factor, the surfactant rhamnolipid, has a significant role in biofilm development $[10,11]$

The molecular mechanisms responsible for biofilm formation in $S$. maltophilia have not been widely studied. Mutants for the glucose-1phosphate thymidyltransferase $r m l A$ gene and for the cis-11-methyl-2dodecenoic acid $r p f F$ gene were reported to decreases biofilm formation $[12,13]$. Further, the $\operatorname{spg} M$ gene, encoding a bifunctional enzyme with both phosphoglucomutase (PGM) and phosphomannomutase activities, is involved in biofilm-forming ability in S. maltophilia [14].

\section{Materials and Methods}

\section{Bacteriological examination}

A total of $\mathbf{6 2 5}$ non-replicated Gram negative non-fermenter bacterial isolates (Acinetobacter baumannii, Pseudomonas aeruginosa and Stenotrophomonas maltophilia) were collected from various specimens (80 wound swap, 80 throat swap, 40 nasal swap, 100 blood, 120 urine, 60 pus, 45 sputum, 50 endotracheal tubes and 50 nasogastric tubes)

*Corresponding author: Elhabibi T, Department of Microbiology and Immunology, Egyptian Russian University, Egypt, Tel: +201004622554; Mobile: +201021411433; E-mail: tamer_elhabibi@yahoo.com

Received June 27, 2017; Accepted July 11, 2017; Published July 18, 2017

Citation: Elhabibi T, Ramzy S (2017) Biofilm Production by Multi Drug Resistant Bacterial Pathogens Isolated From Patients in Intensive Care Units in Egyptian Hospitals. J Microb Biochem Technol 9:151-158. doi: 10.4172/1948-5948.1000359

Copyright: @ 2017 Elhabibi T, et al. This is an open-access article distributed under the terms of the Creative Commons Attribution License, which permits unrestricted use, distribution, and reproduction in any medium, provided the original author and source are credited. 
from ICUs in five hospitals in Egypt (National Cancer Institute, AlKasr eleiny Hospital, Al-Zahraa Hospital, Al-Demerdash Hospital and Al-Galaa Hospital in the period from October 2012 to October 2015. A. baumannii isolates were biochemically identified using catalase test and ability to grow at $44^{\circ} \mathrm{C}[15]$. While, $P$. aeruginosa isolates identified biochemically by both catalase and motility tests, oxidase test $[16,17]$. On the other hand, S. maltophilia isolates were biochemically identified using catalase, motility and Dnase tests [18]. Isolates were confirmed by API 20E test kit (BioMèrieux, France). All isolates were confirmed by detection of specific genes for each microorganism.

\section{Detection of biofilm formation}

Tube method (TM): A qualitative assessment of biofilm formation was evaluated as previously described by Christensen et al. [19]. 10 $\mathrm{mm}$ of trypticase soya broth media with $10 \%$ glucose $\left(\mathrm{TSB}_{\mathrm{glu}}\right)$ was inoculated with loop-full of bacteria from overnight culture plates and incubated at $37^{\circ} \mathrm{C}$ for $24 \mathrm{~h}$. Then the tubes were decanted and washed with phosphate buffer saline PBS (pH 7.4) and dried. Dried tubes stained with crystal violet $(0.1 \%)$. Excess stain was rinsed off by gentle tapping and tubes were washed with deionized water. Tubes were than dried in inverted position and observed for the formation of biofilm. Biofilm formation was considered positive when a visible film lined the wall and bottom of the tube.

Spectrophotometric assay method: The Spectrophotometric assay method described by Christensen et al. is the most commonly used and was considered as standard method for detection of biofilm production [20]. Previous reports have indicated the effect of culture media composition on biofilm formation; therefore we had determined biofilm formation in trypticase soy broth media (TSB Difco), TSB with $1 \%$ glucose $\left(\mathrm{TSB}_{\mathrm{glu}}\right)$. Isolates obtained from fresh agar plates were inoculated in respective media and incubated at $37^{\circ} \mathrm{C}$ for $18-24 \mathrm{~h}$ in stationary condition and diluted 1:100 with fresh medium. Individual wells of sterile, polystyrene, 96 well-flat bottom tissue culture plates (Tarson, Kolkata, India) were filled with $0.2 \mathrm{ml}$ aliquots of the diluted cultures and bacteria free media was used as control. Then tissue culture plates were incubated at $37^{\circ} \mathrm{C}$ for $24 \mathrm{~h}$. After incubation content of each well was removed by gentle tapping the plates. The wells were washed four times with $0.2 \mathrm{ml}$ of phosphate buffer saline (PBS pH 7.4) to remove free-floating 'planktonic' bacteria. Biofilms formed by adherent 'sessile' organisms in plate were fixed with sodium acetate $(2 \%)$ and stained with crystal violet $(0.1 \% \mathrm{w} / \mathrm{v})$. Excess stain was removed by washing with deionized water and plates were kept for drying. Optical density (OD) of stained adherent bacteria was determined with a micro ELISA auto reader (model 680, Bio rad) at wavelength of $590 \mathrm{~nm}($ OD590 nm). The microorganisms were classified into three groups according to the glycocalyx production and biofilm formation that was obtained by O.D. values. The experiment was performed in triplicate; and data was then averaged and plotted.

DNA extraction: DNA was extracted from the bacterial colonies using the QIAmp DNA mini kit (Qiagen Inc.) according to the manufacturer's recommendation. The DNA concentration and purity were determined by measuring the absorbance at $260 \mathrm{~nm}$ and by calculating the ratio of absorbance at $260 \mathrm{~nm}$ to that at $280 \mathrm{~nm}$ using a spectrophotometer (U.V-VIS.), U.V 2500 (Labomed. Inc.) [21]. DNA was used directly or stored at $-20^{\circ} \mathrm{C}$ for future use.

Molecular detection of $16 S$ ribosomal RNA gene for identification of $A$. baumannii strains by polymerase chain reaction (PCR) [22]: Amplification reaction mixtures $(25 \mu \mathrm{l})$ containing 12.5 $\mu \mathrm{l}$ of GoTaq Green master mix 2X (Promega, USA), $2.5 \mu \mathrm{l}(10 \mu \mathrm{M})$ for each forward (AGAGTTTGATCCTGGCTCAG) and reverse (TACCAGGGTATCTAATCCTGTT) gene primers (Kapa, USA), $5 \mu \mathrm{l}$ of DNA template $(100 \mu \mathrm{g})$ and $2.5 \mu \mathrm{l}$ of PCR grade water (Promega) Amplification of the $16 S$ rRNA was performed in a DNA thermal cycler, with the following cycling program: Initial denaturation at $95^{\circ} \mathrm{C}$ for 3 min, and 30 cycles of denaturation at $95^{\circ} \mathrm{C}$ for $1 \mathrm{~min}$, annealing at $55^{\circ} \mathrm{C}$ for $1 \mathrm{~min}$, extension at $72^{\circ} \mathrm{C}$ for $1 \mathrm{~min}$ and a final extension at $72^{\circ} \mathrm{C}$ for 5 min.

Molecular detection of $16 S$ ribosomal DNA gene for identification of $P$. aeruginosa strains by polymerase chain reaction (PCR) [23]: Amplification reaction mixtures (25 $\mu \mathrm{l})$ containing $12.5 \mu \mathrm{l}$ of GoTaq Green master mix 2X (Promega, USA), $2.5 \mu \mathrm{l}$ (10 $\mu \mathrm{M}$ ) for each forward (GACGGGTGAGTAATGCCTA) and reverse (CACTGGTGTTCCTTCCTATA) gene primers (Kapa, USA), $5 \mu \mathrm{l}$ of DNA template $(100 \mu \mathrm{g})$ and $2.5 \mu \mathrm{l}$ of PCR grad water (Promega). Amplification of the $16 S \mathrm{rDNA}$ was performed in a DNA thermal cycler, with the following cycling program: Initial denaturation at $95^{\circ} \mathrm{C}$ for 2 min and 30 cycles of denaturation at $94^{\circ} \mathrm{C}$ for $20 \mathrm{~s}$, annealing at $54^{\circ} \mathrm{C}$ for $20 \mathrm{~s}$, extension at $72^{\circ} \mathrm{C}$ for $40 \mathrm{~s}$ and a final extension at $72^{\circ} \mathrm{C}$ for $1 \mathrm{~min}$.

Molecular detection of $23 S$ rRNA gene for identification of $S$. maltophilia strains by polymerase chain reaction (PCR): Amplification reaction mixtures $(25 \mu \mathrm{l})$ containing $12.5 \mu \mathrm{l}$ of GoTaq ${ }^{\circ}$ Green master mix 2X (Promega, USA), $2.5 \mu \mathrm{l}(10 \mu \mathrm{M})$ for each forward (GCTGGATTGGTTCTAGGAAAACGC) and reverse (ACGCAGTCACTCCTTGCG) gene primers (Kapa, USA), $5 \mu \mathrm{l}$ of DNA template $(100 \mu \mathrm{g})$ and $2.5 \mu \mathrm{l}$ of PCR grad water (Promega). Amplification of the $23 S \mathrm{rRNA}$ was performed in a DNA thermal cycler, with the following cycling program: Initial denaturation at $94^{\circ} \mathrm{C}$ for 5 min, and 30 cycles of denaturation at $95^{\circ} \mathrm{C}$ for $45 \mathrm{~s}$, annealing at $58^{\circ} \mathrm{C}$ for $45 \mathrm{~s}$, extension at $72^{\circ} \mathrm{C}$ for $45 \mathrm{~s}$ and a final extension at $72^{\circ} \mathrm{C}$ for $10 \mathrm{~min}$.

Molecular detection of bap gene which is responsible for biofilm formation in A. baumannii strains by PCR: Amplification reaction mixtures $(25 \mu \mathrm{l})$ containing $12.5 \mu \mathrm{l}$ of GoTaq Green master mix 2X (Promega, USA), $2.5 \mu \mathrm{l}(10 \mu \mathrm{M})$ for each forward (TACTTCCAATCCAATGCTAGGGAGGGTACCAATGCAG) and reverse (TTATCCACTTCCAATGATCAGCAACCAAACCGCTAC) gene primers (Kapa, USA), $5 \mu$ of DNA template $(100 \mu \mathrm{g})$ and 2.5 $\mu \mathrm{l}$ of PCR grad water (Promega). Amplification of the bap gene was performed in a DNA thermal cycler, with the following cycling program: Initial denaturation at $95^{\circ} \mathrm{C}$ for $3 \mathrm{~min}$, and 30 cycles of denaturation at $95^{\circ} \mathrm{C}$ for $1 \mathrm{~min}$, annealing at $56^{\circ} \mathrm{C}$ for $1 \mathrm{~min}$, extension at $72^{\circ} \mathrm{C}$ for $1 \mathrm{~min}$ and a final extension at $72^{\circ} \mathrm{C}$ for $5 \mathrm{~min}$.

Molecular detection of RhlI gene which is responsible for biofilm formation in $P$. aeruginosa strains by PCR [24]: Amplification reaction mixtures $(25 \mu \mathrm{l})$ containing $12.5 \mu \mathrm{l}$ of GoTaq Green master mix 2X (Promega, USA), $2.5 \mu \mathrm{l}(10 \mu \mathrm{M})$ for each forward (CTCTCTGAATCGCTGGAAGG) and reverse (GCGAAGACTTCCTTGAGCAG) gene primers (Kapa, USA), $5 \mu \mathrm{l}$ of DNA template $(100 \mu \mathrm{g})$ and $2.5 \mu \mathrm{l}$ of PCR grad water (Promega). Amplification of the RhlI gene was performed in a DNA thermal cycler, with the following cycling program: Initial denaturation at $94^{\circ} \mathrm{C}$ for 3 min, and 30 cycles of denaturation at $95^{\circ} \mathrm{C}$ for $30 \mathrm{~s}$, annealing at $55.5^{\circ} \mathrm{C}$ for $30 \mathrm{~s}$, extension at $72^{\circ} \mathrm{C}$ for $1 \mathrm{~min}$ and a final extension at $72^{\circ} \mathrm{C}$ for $5 \mathrm{~min}$.

Molecular detection of $r m l A, s p g M, r p f F$ genes which is responsible for biofilm formation in S. maltophilia strains by PCR [14]: For each gene: Amplification reaction mixtures $(25 \mu \mathrm{l})$ containing 12.5 $\mu \mathrm{l}$ of GoTaq Green master mix 2X (Promega, USA), $2.5 \mu \mathrm{l}(10 \mu \mathrm{M})$ 
Citation: Elhabibi T, Ramzy S (2017) Biofilm Production by Multi Drug Resistant Bacterial Pathogens Isolated From Patients in Intensive Care Units in Egyptian Hospitals. J Microb Biochem Technol 9:151-158. doi: 10.4172/1948-5948.1000359

for each forward 5'-GCAAGGTCATCGACCTGG-3' and 5'-TTGCCGTCGTAGAAGTACAGG-3' for $r m l A$, 5'-GCTTCATCGAGGGCTACTACC-3' and 5'-ATGCACGATCTTGCCGC-3' for spgM and, finally, 5'-CTGGTCGACATCGTGGTG-3' and 5'-TGATCCGCATCATTTCATGC-3' for rpfF gene primers (Kapa, USA), $5 \mu$ l of DNA template $(100 \mu \mathrm{g})$ and $2.5 \mu \mathrm{l}$ of PCR grad water (Promega). Amplification of the $r m l A, s p g M, r p f F$ genes were performed in a DNA thermal cycler, with the following cycling program: Initial denaturation at $94^{\circ} \mathrm{C}$ for $5 \mathrm{~min}$ and 30 cycles of denaturation at $95^{\circ} \mathrm{C}$ for $45 \mathrm{~s}$, annealing at $50^{\circ} \mathrm{C}$ for $45 \mathrm{~s}$, extension at $72^{\circ} \mathrm{C}$ for $45 \mathrm{~s}$ and a final extension at $72^{\circ} \mathrm{C}$ for $10 \mathrm{~min}$.

The PCR was performed in a total volume of $25 \mu \mathrm{l}$ reaction mixtures containing $150-200 \mathrm{ng}$ of DNA as template, $0.5 \mu \mathrm{M}$ of each primer and 1x of PCR master mix (Taq Master/High yield, Jena Bioscience) which provides 2.5 units per reaction of DNA polymerase, $0.2 \mathrm{mM}$ of each deoxynucleotide triphosphate, 1x PCR buffer (with $1.5 \mathrm{mM}-\mathrm{MgCl}_{2}$ ). Amplification products were electrophoresed in $2 \%$ agarose gel in $0.5 \mathrm{x}$ TBE (Tris-borate-EDTA) at 70 Volts for $60 \mathrm{~min}$ and visualized under ultraviolet light. To be sure that the amplification products were of the expected size, a 1500 bp DNA ladder was run simultaneously as a marker. Presence of 750 bp, 618 bp, 278 bp, 1500 bp, 245 bp, 82 bp, 80 $\mathrm{bp}$ and $151 \mathrm{bp}$, respectively indicate positive results.

\section{Results}

Three hundred and seventy five, two hundred and fifty isolates of A. baumannii, $P$. aeruginosa and $S$. maltophilia respectively were identified and confirmed by different morphological, biochemical tests. All A. baumannii isolates showed positive results to catalase test and ability to grow on $44^{\circ} \mathrm{C}$. All P. aeruginosa isolates reacted positively to motility, catalase and oxidase tests. All S. maltophilia isolates reacted positively to motility, catalase and Dnase tests. Bacterial isolates were confirmed by API $20 \mathrm{E}$ system showed $90.32 \%$ identification. All isolates of A. baumannii, P. aeruginosa and S. maltophilia respectively were confirmed by PCR assay using specific primers. Peaks for positive samples appeared at $750 \mathrm{bp}, 618 \mathrm{bp}$ and $278 \mathrm{bp}$, respectively as shown in Figures 1-3.

\section{Discussion}

\section{Detection of biofilm formation of bioadherent isolates by PCR}

Detection of bap gene in A. baumannii which is responsible for biofilm formation [25]: Three hundred and seventy five isolates were tested for the presence of bap gene that is responsible for their abilities to produce biofilm using PCR. Three hundred and fifty nine isolates showed positive results and confirmed for the presence of the gene by showing a band on 1500 bp. As illustrated in Figure 4.

Detection of RhlI gene in P. aeruginosa which is responsible for biofilm formation [24]: Two hundred isolates were tested for the presence of RhlI gene that is responsible for their abilities to produce biofilm using PCR. All isolates showed positive results and confirmed for the presence of the gene by showing a band on $245 \mathrm{bp}$. As illustrated in Figure 5.

Detection of $r m l A, s p g M, r p f F$ genes in S. maltophilia which are responsible for biofilm formation [14]: Fifty isolates were tested for the presence of $r m l A, s p g M, r p f F$ genes that are responsible for their abilities to produce biofilm using PCR. 49, 50 and 50 Isolates showed positive results to the three genes respectively by showing a band on 82 bp, $80 \mathrm{bp}$ and $151 \mathrm{bp}$, respectively as illustrated in Figures 6-8.

\section{Tube method}

A qualitative assessment of biofilm production among six hundred and twenty five Gram negative microbial isolates was determined as described before by Christensen et al. [19] (Table 1).

\section{Tissue culture plate method (TCP)}

Assessment of biofilm production among six hundred and twenty five Gram negative microbial isolates was determined as described previously by Christensen et al. [20] (Table 2).

Biofilms play a significant role in bacterial colonization during infection, providing an opportunity for microbe to develop drug

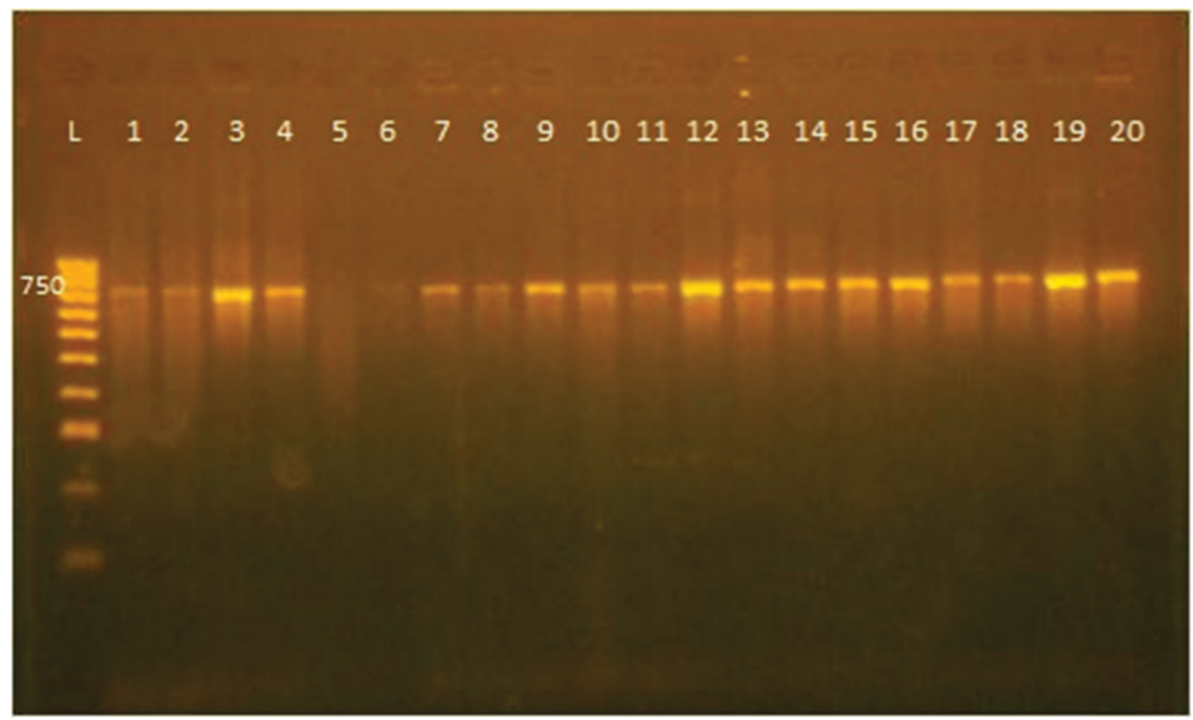

Figure 1: PCR amplification with $16 S$ rRNA gene primers for identification of $A$. baumannii strains.

A 750 bp of 16 S rRNA gene. Lane (L), DNA molecular size marker (I500 bp ladder) and Lanes (1-4) and (6-20) show positive result with positive bands of 750 bp.

Lane (5) shows negative result 
Citation: Elhabibi T, Ramzy S (2017) Biofilm Production by Multi Drug Resistant Bacterial Pathogens Isolated From Patients in Intensive Care Units in Egyptian Hospitals. J Microb Biochem Technol 9:151-158. doi: 10.4172/1948-5948.1000359

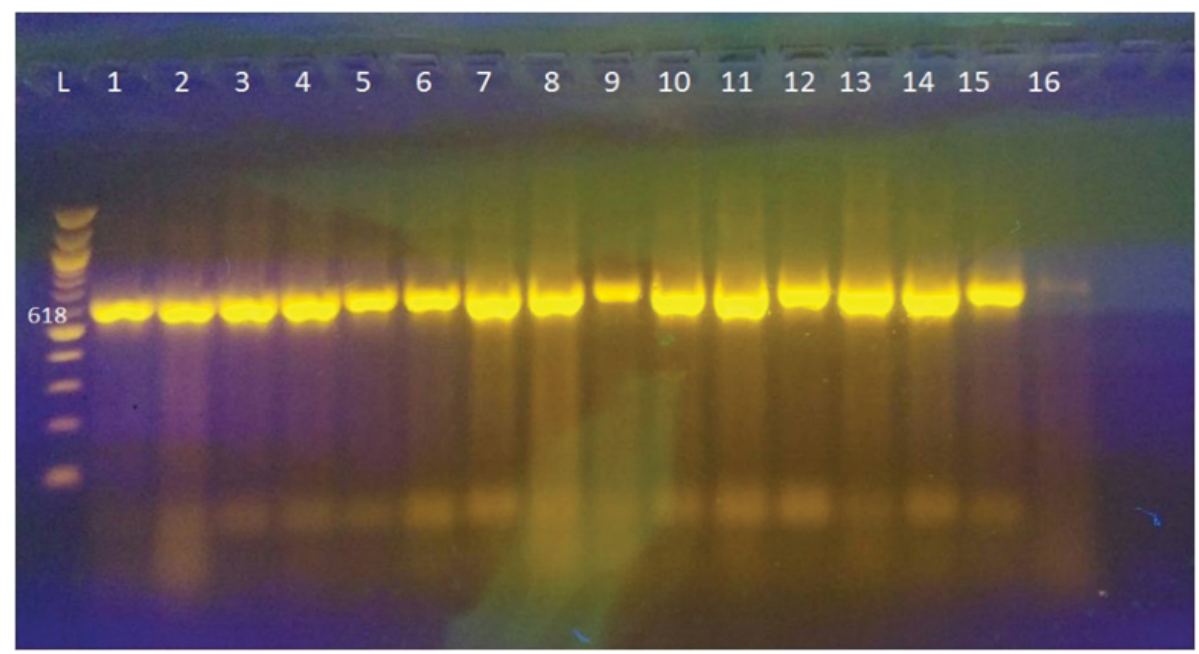

Figure 2: PCR amplification with $16 S \mathrm{rDNA}$ gene primers for identification of $P$. aeruginosa strains.

A 618 bp of $16 S$ rDNA gene. Lane (L), DNA molecular size marker (1500 bp ladder), Lanes (1-16) show positive result with positive bands at 618 bp

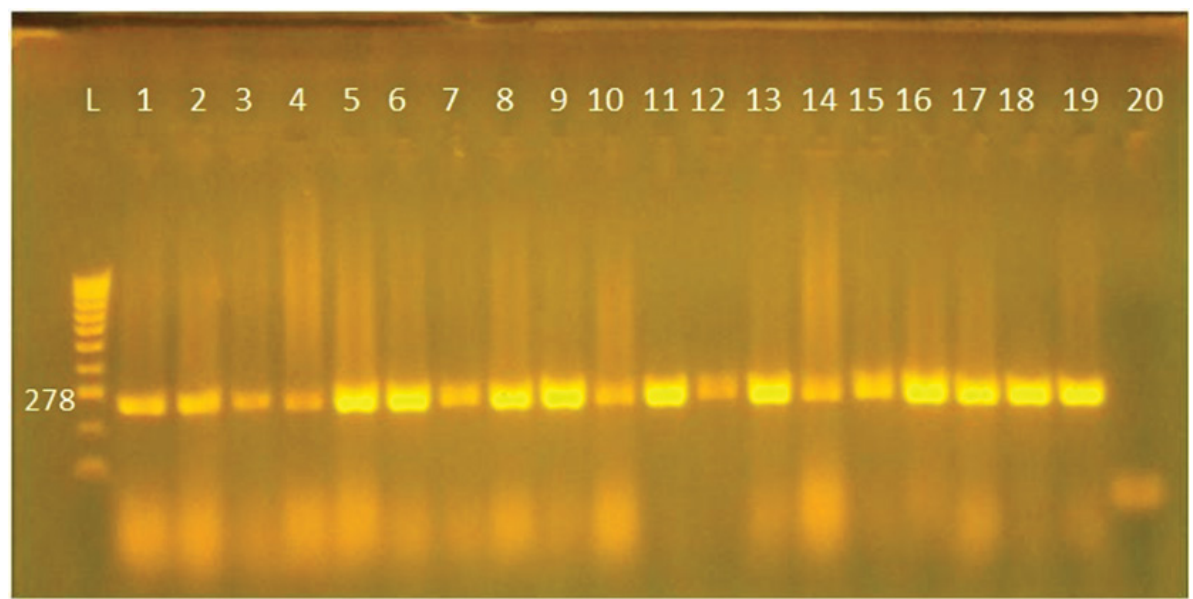

Figure 3: PCR amplification with 23S rRNA gene primers for identification of $S$. maltophilia strains.

A 278 bp of $23 S$ rRNA gene. Lane (L), DNA molecular size marker (1500 bp ladder), Lanes (1-18) show positive result with positive bands of 278 bp. Lane (19) Positive control and Lane (20) negative control

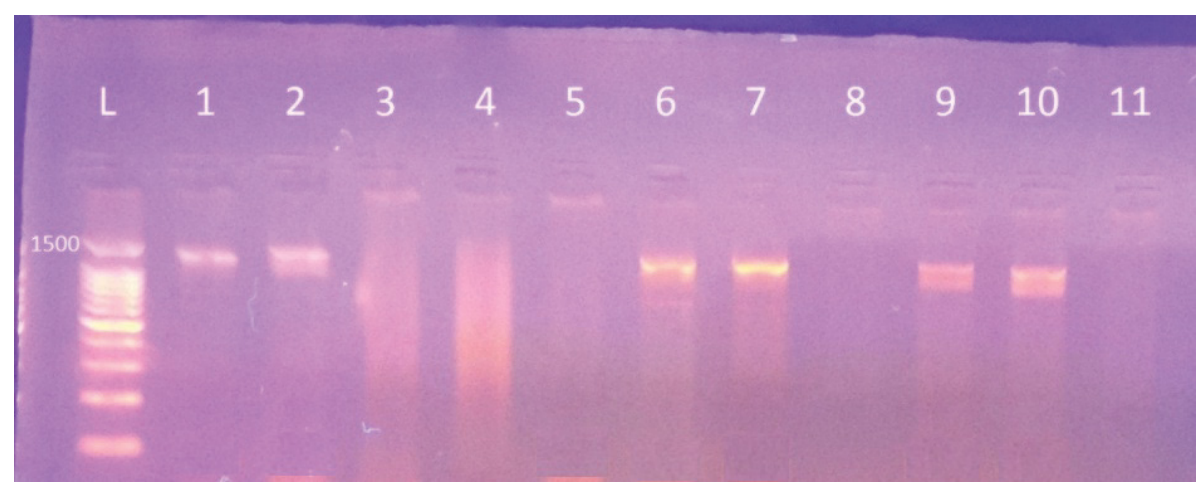

Figure 4: PCR amplification with bap gene primers.

A 1500 bp of bap gene. Lane (L), DNA molecular size marker (I500 bp ladder), Lanes (1-2), (6-7) and (9) show positive result with positive bands of 1500 bp. Lanes (3-5) and Lane (8) show negative result. Lane (10) positive control and Lane (11) negative control 
Citation: Elhabibi T, Ramzy S (2017) Biofilm Production by Multi Drug Resistant Bacterial Pathogens Isolated From Patients in Intensive Care Units in Egyptian Hospitals. J Microb Biochem Technol 9:151-158. doi: 10.4172/1948-5948.1000359

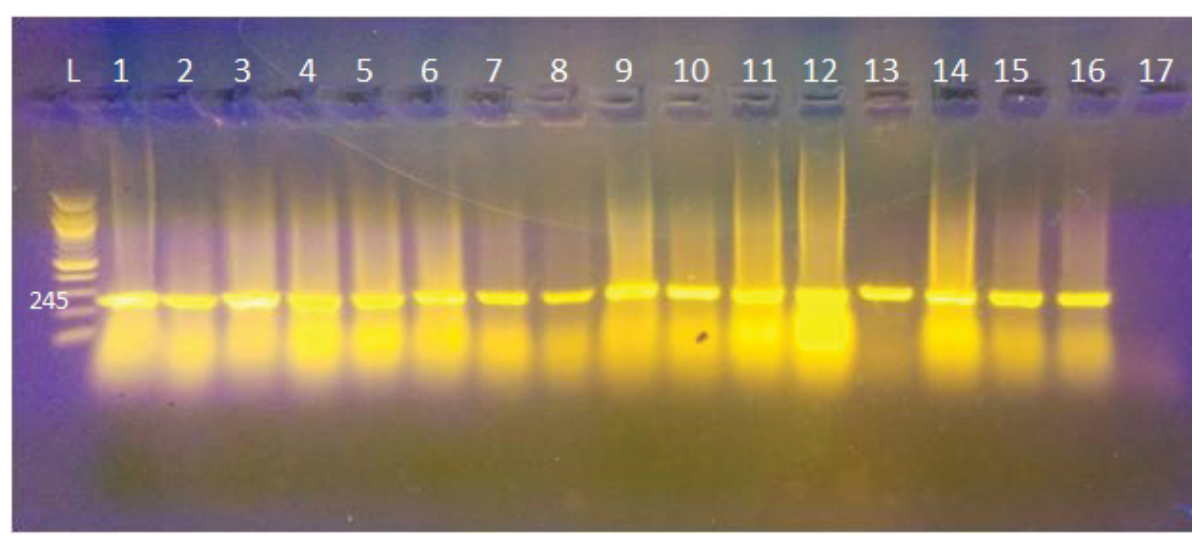

Figure 5: PCR amplification with Rhll gene primers.

A 245 bp of Rhll gene. Lane (L), DNA molecular size marker (1500 bp ladder) and Lanes (1-15) show positive result with positive bands of 245 bp. Lane (16) positive control and Lane (17) negative control

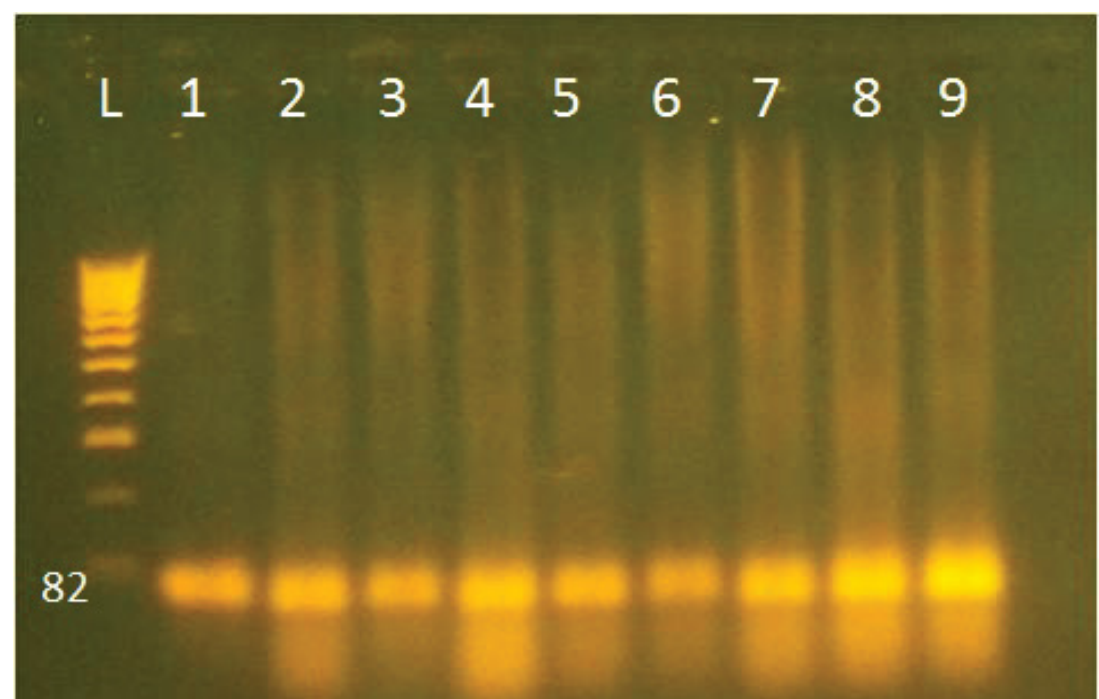

Figure 6: PCR amplification with $r m I A$ gene primers.

A 82 bp of $r$ ImI Lane (L), DNA molecular size marker (1500 bp ladder) and Lanes (1-9) show positive result with positive bands of $82 \mathrm{bp}$

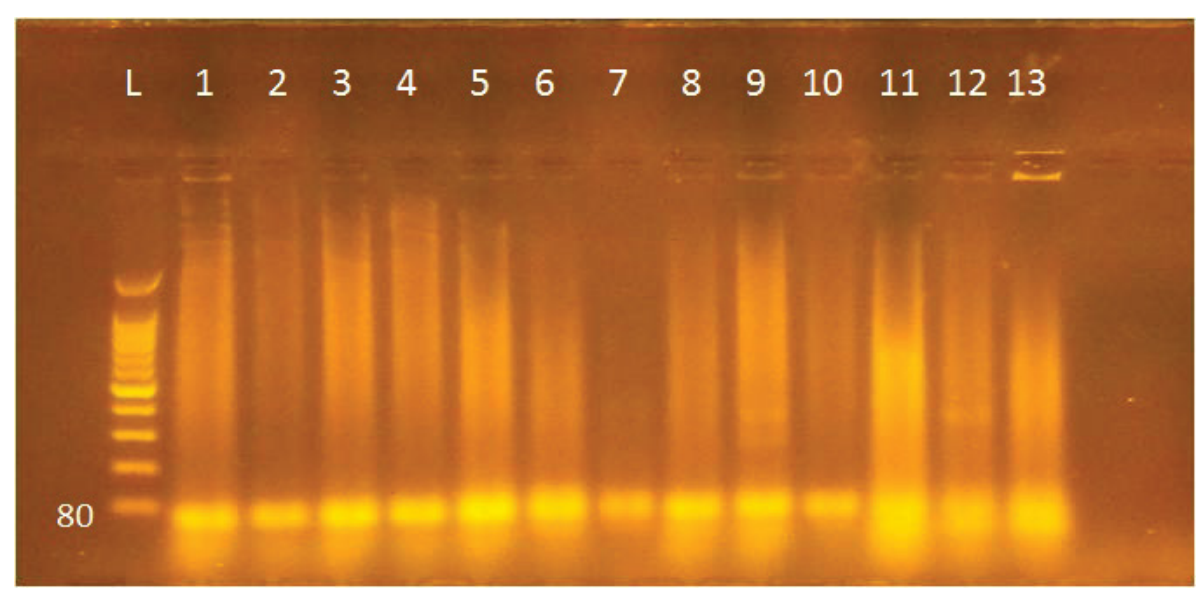

Figure 7: PCR amplification with spgM gene primers.

A 80 bp of spgM. Lane (L), DNA molecular size marker (1500 bp ladder) and Lanes (1-13) show positive result with positive bands of 80 bp 


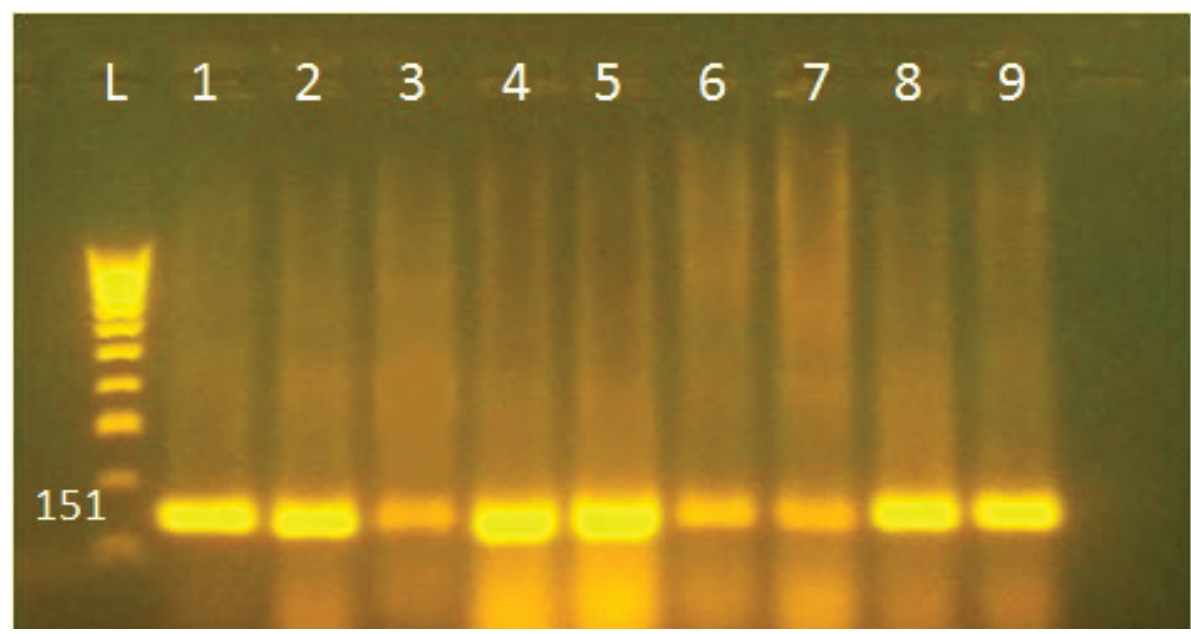

Figure 8: PCR amplification with rpfF gene primers.

A $151 \mathrm{bp}$ of $r$ ffF. Lane (L), DNA molecular size marker (1500 bp ladder) and Lanes (1-9) show positive result with positive bands of $151 \mathrm{bp}$

\begin{tabular}{|c|c|c|c|c|c|}
\hline \multirow[t]{2}{*}{ Micro-organism } & \multicolumn{2}{|c|}{ Non/weakly adherent } & \multicolumn{2}{|c|}{ Strongly adherent } & \multirow{2}{*}{$\begin{array}{c}\text { Total } \\
\text { NO }\end{array}$} \\
\hline & NO & $\%$ & NO & $\%$ & \\
\hline A. baumannii & 75 & 20 & 300 & 80 & 375 \\
\hline P. aeruginosa & 20 & 10 & 180 & 90 & 200 \\
\hline S. maltophilia & 5 & 10 & 45 & 90 & 50 \\
\hline Total & 100 & 16 & 525 & 84 & 625 \\
\hline
\end{tabular}

Table 1: Table shows distribution of bioadherent isolates using tube method.

\begin{tabular}{|c|c|c|c|c|c|c|c|}
\hline \multirow{2}{*}{ Micro-organism } & \multicolumn{2}{|c|}{ Non adherent } & \multicolumn{2}{c|}{ Moderately adherent } & \multicolumn{2}{c|}{ Strongly adherent } & Total \\
\cline { 2 - 8 } & NO & $\%$ & NO & $\%$ & NO & NO \\
\hline A. baumannii & 18 & 4.8 & 57 & 15.2 & 300 & 80 & 375 \\
\hline P. aeruginosa & 0 & 0 & 20 & 10 & 180 & 90 & 200 \\
\hline S. maltophilia & 2 & 4 & 5 & 10 & 43 & 86 & 50 \\
\hline Total & 20 & 3.2 & 82 & 13.1 & 523 & 83.7 & 625 \\
\hline
\end{tabular}

Table 2: Table shows distribution of bio adherent isolates using Tissue culture plate method (TCP).

resistance [26]. Biofilms are estimated to be responsible for over $65 \%$ of nosocomial infections and $60 \%$ of all human bacterial infections $[27,28]$. The most commonly studied bacteria capable of forming biofilms are A. baumannii, $P$. aeruginosa and S. maltophilia. Biofilm formation is important in establishing infections on different host tissues as well as different medical devices in hospital acquired infections in Egyptian hospitals ICUs [7]. In these settings, the antibiotic resistance engendered by biofilms presents a serious challenge to the treatment of nosocomial infections caused by MDR bacteria [7].

Six hundred and twenty five Gram negative isolates (A. baumannii, $P$. aeruginosa and $S$. maltophilia) were isolated and tested for their abilities to form biofilm using tube method, tissue culture plate method and genetically. Twenty isolates (3.2\%) were non/weakly adherent, 82 isolates (13.1\%) were moderately adherent and 523 isolates (83.7\%) was strongly adherent.

According to the results of the tube tests, $84 \%$ of the tested strains produced biofilm. The tube adherence assay is easy and simple although reading of the results may be somehow complicated. Furthermore, observers repeatedly have different interpretations about weak reactions [29]. However, other tests can give better interpretation as tissue culture plate method, where the bacterial culture is transferred to a well of a microtiter plate and read by ELISA plate reader, subsequently the approach was changing from a qualitative to a quantitative one. The quantitative microtiter-plate test predicts clinical applications more reliable than the tube testing [30]. In this study, no significant disagreement between the tube test results and microtiter-plate was observed. While in the study conducted by Abdi-Ali et al., considerably more strains were classified as weak adherent by the quantitative microtiter-plate method [31]. Factors that may affect the adherence of A. baumannii, $P$. aeruginosa and S. maltophilia including the hydrophobicity of the test tubes and shaking which raises the chances of bacterial interaction with the glass surface and uniform nutrients dispersion, which may be the main reasons for the difference in results between both studies.

Microtiter plate test is a very vulnerable, precise, reproducible and inexpensive method for screening the biofilm production and can function as a reliable quantitative test for determining biofilm production. Results of microtiter plate method confirmed by the molecular detection of specific genes responsible for biofilm formation by many MDR bacteria as $A$. baumannii which might increase the colonization and persistence of bacteria that may lead to higher rates of device related infections [31].

Biofilm production is an important feature of $A$. baumannii as it readily adheres to inanimate surfaces and hence facilitate colonization 
and infection in the hospital setting [32,33]. Biofilms are difficult to get rid of as they are highly dense colonies of A. baumannii and exhibit high levels of resistance to antibiotics [34].

Our study revealed that $80 \%$ of $A$. baumannii isolates were strongly adherent, while $15.2 \%$ were moderately adherent and $4.8 \%$ were non adherent. These results was higher than that presented by Abdi-Ali et al. in Tehran, which presented that $28 \%$ of the isolates were strongly adherent, while $41 \%$ were moderately adherent and $25 \%$ were non adherent [31]. This difference may come from the genetic diversity of MDR A. baumannii isolates between Egyptian and Iranian hospitals.

Detection of bap gene in A. baumannii which is responsible for biofilm formation showed $100 \%$ occurrence in all isolates which are moderately adherent and strongly adherent, these results nearly resembles that presented by Goh et al. which was $92 \%$ [25].

In our study, all isolates $P$. aeruginosa were biofilm producers by microtiter plate method using CV assay; 180 isolates (90\%) were strong biofilm producers; 20 isolates (10\%) were moderate biofilm producers and 4 isolates $(8 \%)$ were weak biofilm producers. Similar results were obtained in another study in Egypt conducted by Abd El-Galil et al. as all isolates were biofilm producers by microtiter plate method using CV assay; 42 isolates (84\%) were strong biofilm producers; 4 isolates $(8 \%)$ were moderate biofilm producers and 4 isolates $(8 \%)$ were weak biofilm producers [24]. Also, these results were confirmed by another study performed in Egyptian hospitals by Hisham et al., as all isolates were biofilm producers using CV assay; 16 isolates (80\%) were strong biofilm producers; 2 isolates (10\%) were moderate biofilm producers and 2 isolates (10\%) were weak biofilm producers [35].

In the present study, RhlI gene was detected in all biofilm forming isolates suggesting that RhlI gene might be involved in biofilm production. This suggestion is confirmed by a previous study in Egypt by Abd El-Galil et al. who reported that $100 \%$ of $P$. aeruginosa isolates showed the presence of RhlI gene that proved that RhlI gene is responsible for biofilm formation [24]. Moreover, another study in Switzerland revealed that biofilm production was reduced by $70 \%$ in RhlI mutant strain of $P$. aeruginosa comparing to its parent strain indicating the role of RhlI gene in biofilm formation [36]. Also in another study in USA, they showed that if QS inhibitory compounds shut down RhlI expression, then all the other genes in the QS cascade would be shut down also, including those involved in biofilm formation that strengthens RhlI role in biofilm formation [37-39].

\section{Conclusion}

Our results revealed that $r m l A, s p g M, r p f F$ genes in S. maltophilia which are responsible for biofilm formation showed $100 \%$ occurrence in all isolates which are moderately adherent and strongly adherent, these results shows little difference than that presented by Pompilio et al. which showed an overall prevalence of $65.2,88.8$ and $61.8 \%$, respectively [14]. This difference may come from the genetic diversity of MDR S. maltophilia isolates between Egyptian and overseas hospitals worldwide.

\section{References}

1. Tenke P, Köves B, Károly N, Hultgren SJ, Mendling W, et al. (2012) Update on biofilm infections in the urinary tract. World J Urol 30: 51-57.

2. Hoiby N, Bjarnsholt T, Givskov, Molin S, Ciofu O (2010) Antibiotic resistance of bacterial biofilms. Int J Antimicrob Agents 35: 322-332.

3. Hoiby N, Ciofu O, Johansen HK, Song ZJ, Moser C, et al. (2011) The clinical impact of bacterial biofilms. Int J Oral Sci 3: 55-65.
4. El-Azizi M, Farag N, Khardor N (2016) Efficacy of selected biocides in the decontamination of common nosocomial bacterial pathogens in biofilm and planktonic forms. Comp Immunol Microbiol Infect Dis 47: 60-71.

5. Hengzhuang W, Wu H, Ciofu O, Song Z, Hoiby N (2011) Pharmacokinetics/ pharmacodynamics of colistin and imipenem on mucoid and non-mucoid pseudomonas aeruginosa biofilms. Antimicrob Agents Chemother 55: 44694474.

6. Gaddy JA, Tomaras AP, Actis LA (2009) The Acinetobacter baumannii 19606 OmpA protein plays a role in biofilm formation on abiotic surfaces and in the interaction of this pathogen with eukaryotic cells. Infect Immun 77: 3150-3160.

7. El-Khashaab TH, Erfan DM, Kamal A, El-Moussely LM, Ismail DK (2016) Pseudomonas aeruginosa biofilm formation and quorum sensing lasr gene in patients with wound infection. Egy J Med Microbiol 25:101-108.

8. Juhas M, Eber L, Tummler B (2005) Quorum sensing: the power of cooperation in the world of Pseudomonas. Environ Microbiol 7: 459-471.

9. Schuster M, Greenberg EP (2006) A network of networks: Quorum sensing gene regulation in Pseudomonas aeruginosa. Int J Med Microbiol 296:73-81.

10. Davey ME, Caiazza NC, O'Toole GA (2003) Rhamnolipid surfactant production affects biofilm architecture in Pseudomonas aeruginosa PAO1. J Bacteriol 185: 1027-1036.

11. Boles BR, Thoendel M, Singh PK (2005) Rhamnolipids mediate detachment of Pseudomonas aeruginosa from biofilm. Mol Microbiol 57:1210-1223.

12. Fouhy Y, Scanlon K, Schouest K, Spillane C, Crossman L, et al. (2007) Diffusible signal factor-dependent cell-cell signaling and virulence in the nosocomial pathogen Stenotrophomonas maltophilia. J Bacteriol 189:4964-4968.

13. Huang TP, Somers EB, Wong AC (2006) Differential biofilm formation and motility associated with lipopolysaccharide/exopolysaccharide-coupled biosynthetic genes in Stenotrophomonas maltophilia. J Bacteriol 188: 31163120 .

14. Pompilio A, Pomponio S, Crocetta V, Gherardi G, Verginelli F, et al. (2011) Phenotypic and genotypic characterization of Stenotrophomonas maltophilia isolates from patients with cystic fibrosis: Genome diversity, biofilm formation, and virulence. BMC Microbiol 11:159.

15. Schreckenberger PC (2003) Acinetobacter, Achromobacter, Chryseobacterium, Moraxella and other non-fermentative gram-negative rods, Washington, DC ASM Press.

16. Koneman EW, Allen SD, Janda WM, Schreckenberger PC, Winn WCW (1997) Color Atlas and Textbook of Diagnostic Microbiology. 5th. ed. J.B LippincottRaben Publ.

17. Cheesbrough M (2006) District laboratory practice in tropical countries (Part 2) Cambridge Univ press

18. Murray PR (2007) Manual of Clinical Microbiology. 9th ed. Washington, D.C ASM Press.

19. Christensen GD, Simpson WA, Bisno AL, Beachey EH (1982) Adherence of slime-producing strains of Staphylococcus epidermidis to smooth surfaces. Infect Immun 37: 318-326.

20. Christensen GD, Simpson WA, Younger JA, Baddour LM, Barrett FF (1985) Adherence of coagulase negative Staphylococci to plastic tissue cultures: A quantitative model for the adherence of Staphylococci to medical devices. J Clin Microbiol 22: 996-1006.

21. Sambrook J, Fritsch E, Maniatis T (1989) Molecular cloning: A laboratory manual, second edition. Cold Spring Harbor Laboratory Press.

22. Misbah S, Hassan H, Yusof MY, Hanifah YA, AbuBakar S (2005) Genomic species identification of Acinetobacter of clinical isolates by 165 rDNA sequencing. Singapore Med J 46: 461.

23. Spilker T, Coenye T, Vandamme P, LiPuma JJ (2004) PCR-based assay for differentiation of Pseudomonas aeruginosa from other Pseudomonas species recovered from cystic fibrosis patients. J Clin Microbiol 42: 20274-2079.

24. AbdEIGalil K, AbdelGhani SM, Sebak MA, El-Naggar W (2013) Detection of biofilm genes among clinical isolates of Pseudomonas aeruginosa recovered from some Egyptian hospitals. N Egypt J Microbiol: 36.

25. Goh HMS, Beatson SA, Totsika M, Moriel DG, Phan M, et al. (2013) Molecular analysis of the Acinetobacter baumannii biofilm-associated protein. Appl Environ Microbiol 79: 6535-6543. 
Citation: Elhabibi T, Ramzy S (2017) Biofilm Production by Multi Drug Resistant Bacterial Pathogens Isolated From Patients in Intensive Care Units in Egyptian Hospitals. J Microb Biochem Technol 9:151-158. doi: 10.4172/1948-5948.1000359

26. Matthew W (2006) A Performance standards for antimicrobial susceptibility testing: Sixteenth informational supplement. Clin Lab Stand Inst.

27. Römling U, Balsalobre C (2012) Biofilm infections, their resilience to therapy and innovative treatment strategies. J Inter Med 272: 541-561.

28. Boyle KP, Heilmann S, Ditmarsch DV, Xavier JB (2013) Exploiting social evolution in biofilms. Curr Opin Microbiol: 16:1-6.

29. Srdjan S, Dragana V, Ivana D, Branislava S, Milena SV (2000) A modified microtiter-plate test for quantification of Staphylococcal biofilm formation. J Microbiological Methods 40:175-179.

30. Kazemi PN, Dusane DH, Dhakephalkar PK, Zamin FR, Zinjarde SS, et al. (2011) Biofilm formation by Acinetobacter baumannii strains isolated from urinary tract infection and urinary catheters. FEMS Immunol Med Microbio 62:328-338.

31. Abdi-Ali A, Hendiani S, Mohammadi P, Gharavi S (2014) Assessment of biofilm formation and resistance to imipenem and ciprofloxacin among clinical isolates of Acinetobacter baumannii in Tehran. Jundishapur J Microbiol 7: e8606.zafer.

32. Gordon NC, Wareham DW (2009) A review of clinical and microbiological outcomes following treatment of infections involving multidrug-resistant Acinetobacter baumannii with tigecycline. J Antimicrob Chemo 63: 775-780.
33. Peleg AY, Seifert H, Paterson DL (2008) Acinetobacter baumannii: Emergence of a successful pathogen. Clin Microbiol. Rev 21: 538-582.

34. Al-Hassan L, El Mehallawy H, Amyes SG (2013) Diversity in Acinetobacter baumannii isolates from pediatric cancer patients in Egypt. Clin Microbio Infect19: 1082-1088.

35. Hisham AA, Fathy MS, Eman ME (2012) Combating Pseudomonas aeruginosa Biofilms by Potential Biofilm Inhibitors. Asian J Res Pharm Sci 2: 66-72.

36. Favre-Bonté S, Köhler T, Van Delden C (2003) Biofilm formation by Pseudomonas aeruginosa: role of the C4-HSL cell-to-cell signal and inhibition by azithromycin. J Antimicrob Chemother 52: 598-604.

37. De Kievit TR, Gillis R, Marx S, Brown C, Iglewski BH (2001) Quorum-sensing genes in Pseudomonas aeruginosa biofilms: Their role and expression patterns. Appl Envir Microbiol 67: 1865-1873.

38. Schuster M, Greenberg EP (2006) A network of networks: Quorum sensing gene regulation in Pseudomonas aeruginosa. Int J Med Microbiol 296: 73-81.

39. Gallo SW, Ramos PL, Ferreira CAS, De Oliveira SD (2013) A specific polymerase chain reaction method to identify Stenotrophomonas maltophilia. Mem Inst Oswaldo Cruz 108: 390-391. 